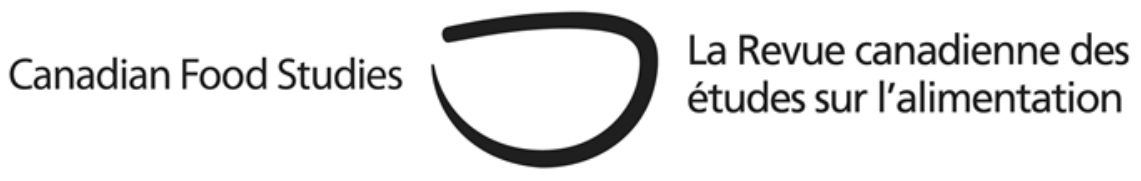

Original Research Article

\title{
Food pedagogy for transformative social change
}

\author{
Chelsea Klinke* and Gertrude Korkor Samar \\ University of Calgary
}

\begin{abstract}
The contemporary global agrarian regime has altered patterns of food production, circulation, and consumption. Its efforts toward food security vis-á-vis capitalist modes of mechanized cultivation have produced large-scale climatic and socioeconomic ramifications. To improve the dynamics of dominant agricultural systems, practitioners and scholars are engaging in a critical analysis of food pedagogy. We argue that a gap exists between Food Studies scholarship and community-based transformative engagement. To support local food systems through activist scholarship, our paper calls for an academic paradigm shift wherein learner-centred experiential classrooms bridge academic-public divides and enhance student learning. Through a reflexive case study of urban farming in Calgary, we provide strategies for building leadership and technical skills in advanced urban farming while strengthening intercultural relationships. We conclude by evaluating the success of our approach, presenting potential benefits and challenges, and offering pathways within food scholarship to align with grassroots movements.
\end{abstract}

Keywords: Food pedagogy; activist scholarship; experiential (EXL); participatory; food systems; food security; social change; transformative; community; agroecology 
Introduction

Until recently, discourse in Food Studies pedagogy - the various ways that instructors, activists, and communities are teaching, learning, and intervening in their food processes (Meek \& Tarlau, 2016) - has largely highlighted the role and impact of mechanized industrial agriculture (Frison, 2016; Kremen et al., 2012). This tendency has encompassed both the social and ecological ramifications of an agrarian regime that emphasizes market privatization, distribution corporatization, and extractive-led development platforms (Bernstein, 2009; Horrigan et al., 2002; IRP, 2019). With the emergence of "critical agrarian studies," this analysis was broadened to ask key agrarian questions, including 1) who owns what?; 2) who does what?; 3) who gets what?; and 4) what do they do with it? (Bernstein, 2010). Indeed, dialogues and debates concerning the feminization of agriculture, large-scale land acquisitions, food sovereignty, and the financialization of food have gained momentum (Akram-Lodhi et al., 2021; Borras et al., 2012; Bernstein, 2016; Edelman \& Wolford, 2017; McKay, 2017). However, we argue that a gap still exists for the convergence of classroom-based food scholarship and experiential learning (EXL) within sustainable community food models to cultivate transformative social change.

As active participants in the agrarian communities and institutes we wish to change, we highlight our experiences as anthropology graduate students engaged in food pedagogies. Before COVID-19 halted our respective fieldwork, we were scheduled to conduct participatory research alongside farmers internationally during the summer of 2020. In response, we attuned our lenses to local agrarian systems, observing gaps in access and security over healthy food choices in Calgary, Canada. Over the course of a four-month University of Calgary Transformative Talent Internship with a not-for-profit peri-urban farm, Grow Calgary, we asked the questions: How can the incorporation of community-driven food movements in academic frameworks cultivate awareness and action surrounding more socially and ecologically-just agrarian models? How can this shift support student learning and build resilient communities?

In our intern capacities as Executive Director and Community Outreach Coordinator, we worked with volunteers to cultivate produce to donate to social agencies with food access programmes for Calgarians living below the poverty line. To address challenges faced by Calgary's food-insecure populations, we present strategies for bridging the academic-public divide through activist scholarship that directly engages with sustainable urban and agrarian development. Our results indicate that running course-based theory and literature alongside applied methodologies that build the technical and leadership capacity of post-secondary students yields numerous positive outcomes. Namely, it enhances student learning of food systems, builds stronger community ties, and supports economically viable, socially just, and environmentally sustainable food systems that improve food access opportunities for marginalized communities. We conclude by discussing and evaluating the success of our approach, identifying the limitations (i.e., online learning during the COVID-19 pandemic) and potential benefits to students who engage in Food Studies programmes, and making recommendations for best practices in food pedagogy that will support social change. 


\section{Activist food pedagogy}

Food Studies educators are gradually making efforts to help students engage with food-related issues by expanding post-secondary scholarship beyond the classroom. This is characterized by curricular re-design and pedagogical approaches centred on student learning and application (Salomonsson et al., 2009). Within food pedagogy, there has been a noticeable shift from a teacher-centred to a learner-centred praxis. On the one hand, conventional teacher-centred instructional techniques privilege the instructor as the sole source of knowledge in the classroom - one who disseminates information to students principally through lectures reflecting content-heavy textbooks (Hilimire et al., 2014). Such siloed approaches are narrowly focussed without substantial opportunities for interdisciplinarity (Dole et al., 2015; Galt et al., 2012; Salomonsson et al., 2009). Moreover, this archetypical classroom environment places a higher value on competition over collaboration, resulting in fewer meaningful relationships among students (Wiedenhoeft et al., 2003).

On the other hand, in a learner-centred approach, which shifts the focus from the teacher to the student, "students construct knowledge through gathering and synthesizing information and integrating it with the general skill of inquiry, communication, critical thinking and problemsolving" (Huba \& Freed, 2000, p. 5). Grounded in participation, experience, and action (Galt et al., 2012), both students and teachers create and evaluate the learning process together, while emphasizing more attuned questions and self-reflexivity. Scholars have argued that this paradigm shift in food pedagogy has been informed by an emphasis for more sustainable modes of agriculture as a result of climatic and socio-economic implications of the global agro-food system (Francis et al., 2012; Lieblein \& Francis, 2007).

Environmental and social sustainability issues in agro-food systems are receiving increasing attention, as demonstrated by a rising interest in farming and food within academic circles and among the general population (Alkon \& Agyeman, 2011; Lieblein \& Francis, 2007; Parr et al., 2007). There is also an observed movement of students enrolling in Food Studies courses that focus on important issues in local and global communities. Food Studies educators are distinguishing themselves from other pedagogical means by combining systems-thinking, group learning, and a direct connection between theory and practice (Francis et al., 2011; Hilimire et al., 2014; Lieblein \& Francis, 2007).

Curricular design within many food systems programmes is also encouraging collaboration between diverse faculties, whose lessons draw upon disparate disciplinary perspectives (Francis et al., 2011; Parr et al., 2007). Moreover, the gradual incorporation of EXL in Food Studies courses has become a pillar in the effort to bridge the gap between the theory and practice (Lieblein et al., 2004; Parr \& Trexler, 2011). Experiential learning opportunities in food systems education range from internships at farms and gardens, ranches, and social agencies, to participating in food justice campaigns and policy reforms (Hilimire et al., 2014). These provide students with critical, self-reflective learning experiences that heighten their consciousness about 
academic, personal, and civic relationships to food and food systems (Galt et al., 2013; Niewolny \& Lillard, 2010; Parr \& Trexler, 2011). Peer-to-peer learning opportunities also open the doors for more distributed knowledge to be shared among diverse stakeholders in the community and experiential classroom (Alkon \& Guthman, 2017).

One can observe activist scholars, practitioners, and organizations around the world engaging in food justice with the aim of dismantling uneven power dynamics in agrarian systems both at local and global levels (Reynolds et al., 2018: McEntee \& Naumova, 2012). A central objective in this endeavour is supporting and building the capacity of marginalized communities through platforms of knowledge mobilization (Casas-Cortés et al., 2008; Choudry \& Kapoor, 2010) and social justice frameworks (Calhoun, 2008) determined by the communities themselves. Thus, when engaging in activist scholarship, one must draw from participatory experiences that contribute to positive social change.

Food pedagogy has evolved to address the interconnectedness between social and ecological dynamics of food systems, including production, harvesting, processing, distribution, consumption, and waste management (Knezevic et al., 2017; Stephens et al., 2019). Much of this growing critical scholarship has focussed on capitalism and the implications for social and ecological relations in systems, including, but not limited to, land appropriation, exploitation, inequity, and health (Alkon \& Agyeman, 2011; Alkon \& Guthman, 2017). Scholars are contributing immensely to sustainable food systems debates by adopting creative and engaged theoretical and methodological approaches, and through collaborations with practitioners eager to support community-based food activism (Levkoe et al., 2020). In addition to epistemic critiques of the structural production of food injustices, activist scholars can contribute to the generation and channeling of resources to support the work of non-academic activists (Derickson \& Routledge, 2015; Duncan et al., 2019). In the following section, we present our experiences with activist food scholarship through a case study approach with the not-for-profit farm Grow Calgary. As our internships were not directly related to our respective theses, and therefore did not secure ethics approval for working with human subjects, community perspectives will not be discussed in this paper. From our lens as graduate students, we demonstrate how food pedagogy may be grounded in experiential learning to address urban food insecurity through a transformative agenda.

\section{Experiential learning at Grow Calgary}

Grow Calgary (www.growcalgary.ca) is a twelve-acre peri-urban farm in Balzac, Alberta, that grows fresh produce for social agencies serving food-insecure populations within Calgary, originally known as Moh'kinstsis (MOH-kin-stsis) in the Blackfoot language. Translated as "elbow" in English, Moh'kinstsis references the confluence of the Elbow and Bow Rivers, which flow from the Rocky Mountain glaciers to the watersheds of our contemporary 
urban landscape. These waters and lands have been stewarded since time immemorial by the Indigenous Peoples of Treaty 7 region in Southern Alberta. Treaty 7 signatories include the Blackfoot Confederacy, comprising of the Siksika, Piikani, and Kainai First Nations; the Tsuut'ina Denè First Nation; and the İyethka (Stoney) Nakoda, including the Chiniki, Bearspaw, and Wesley First Nations. Calgary is also home to Métis Nation of Alberta, Region III, as well as Indigenous and non-Indigenous kin from around the world, including the Inuit. We have been privileged to work, learn, and live on these lands as visitors and interns of Grow Calgary.

Kick-starting a farm situated on a new swath of land from scratch proved to be exhilarating and challenging, requiring administrative structures and interns, such as ourselves, to supervise over 500 volunteers on and off the farm. Drawing on the professional and interpersonal skills honed during our graduate programme, we supported voluntary coordinators in sixteen departments, including material procurement, fundraising, policy, information technology, and more. To connect with the Calgary community, we mobilized volunteers and group days with youth and social agencies, such as the national Katimavik volunteer programme. To reach wider audiences and increase awareness about the organization's efforts to address food insecurity, we conducted interviews with local news stations, including CBC, CTV, and CJSW. Through Grow Calgary's social media platforms and weekly newsletter, we connected over 12,000 "followers" with activities, educational programmes, sponsors, and cultivation tips from the farm. This network has since expanded beyond Grow Calgary to connect us with other agrarians in and around the city.

Akin to developing a semester-long curriculum with a core learning objective and subsequent learning targets — skills that we acquired as graduate teaching assistants — we created strategic plans that aligned with the organization's overarching mission to guide us in our offfarm positions. Norms and expectations were created in a collaborative manner, which we reflected upon during monthly all-staff meetings. Each week, we established goals, monitored and evaluated our progress, and reported updates to our immediate supervisors. Departments were encouraged to "cross-pollinate" and work with one another to achieve common goals.

To build technical and leadership capacity on the farm, we developed a free and flexible Small-Scale Agricultural Farm Management Certificate Programme. Seventy learning targets were thematically characterized and scaffolded with specific, measurable, attainable, relevant, and time-bound (SMART) goals (Lawlor \& Hornyak, 2012). Each target aligned with the organization's meta transformative agenda of bolstering food security in Calgary through a more ecologically sustainable and socially-just agrarian model. Situating ourselves in a larger web of life guided how we operationalized our learning targets to strengthen soil health, water, and resource conservation, and biotic diversity. 
For instance, "by the end of my certificate programme, I will be able to: Facilitate discussions on the ecological benefits of small-scale agriculture; space and rotate crops to ensure maximum resource allocation and soil conservation; construct 'lasagna beds'/sheet mulching for no-till planting (Figure 1); optimize the use of low-impact local resources, such as compost; 'chop and drop' at the end of the harvest season to enhance soil structure; and reduce high-impact technologies and energy-intensive inputs by supporting regenerative practices."

Figure 1: No-till lasagna beds with polycultures.

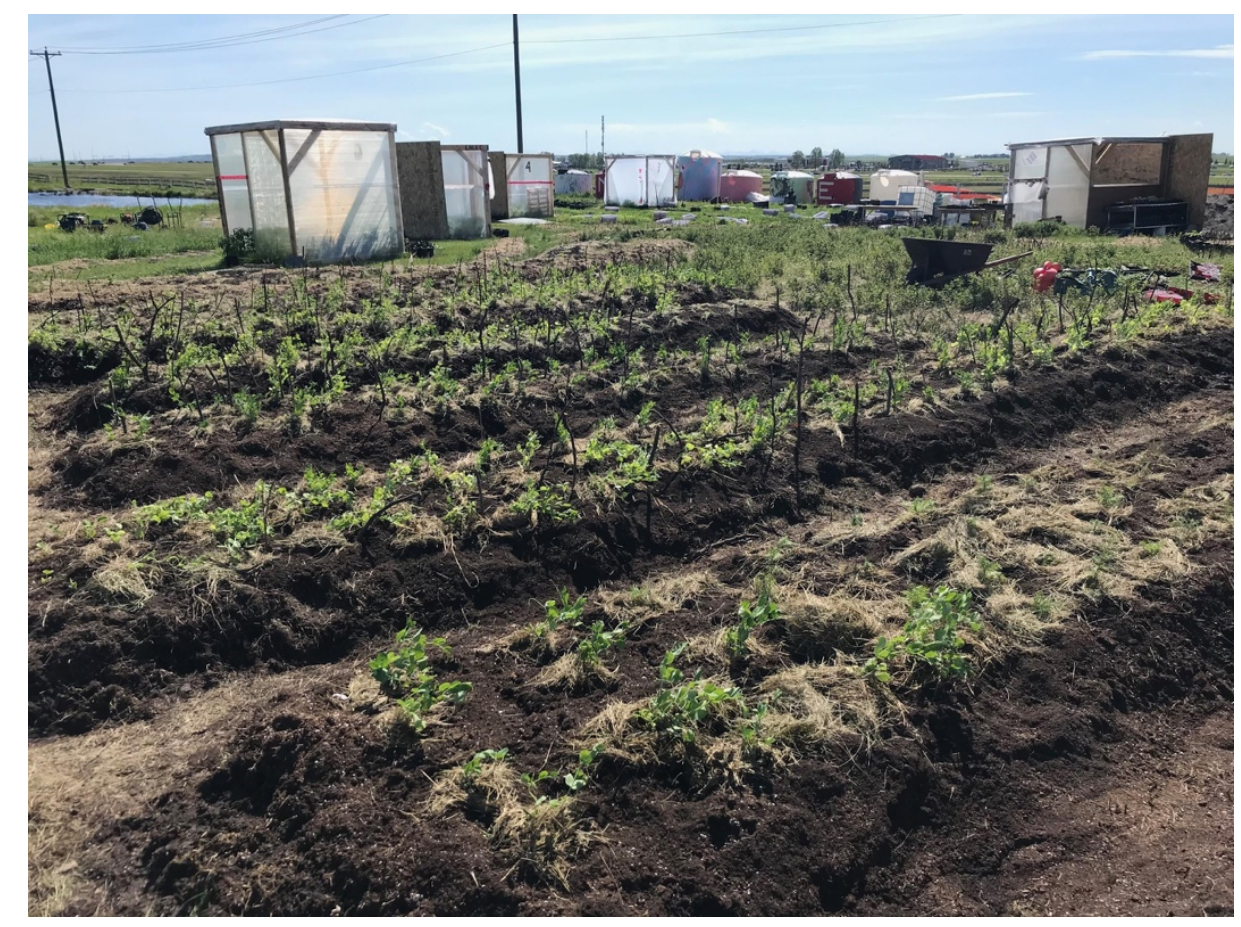

At the end of each shift, we learned the best practices for harvesting and transporting produce (Figure 2) to deliver straight to the chefs of our twenty-one partnering food access agencies, such as The Leftovers Foundation (https://rescuefood.ca/), Inn From the Cold (https://innfromthecold.org/), and Calgary Women's Emergency Shelter (https://www.calgarywomensshelter.com/). Interacting with members of the community was one of the most rewarding aspects of our experiences with Grow Calgary - an opportunity we typically did not have in conventional classroom settings. Another way in which we built community relationships was through Grow Calgary's \#Kits4Kids initiative. Kits included a tray, dome, soil, seeds, and pots, which were donated to low-income families in Calgary, along with an instructional pamphlet. The goal of this project was to increase the capacity of youth to grow fresh food from home. When the call was sent out via our social media platforms between February and April of 2020, over 10,000 Calgarians signed up to receive kits. 
We believe that this heightened interest in food access and security at the household level was in response to the COVID-19 quarantine mandate, which began in March 2020 in Calgary. An upward trend in gardening was also reflected in the lack of available seeds, soil, and other growing materials at garden centres around the city.

Figure 2: Fresh produce for a Calgary-based social agency.

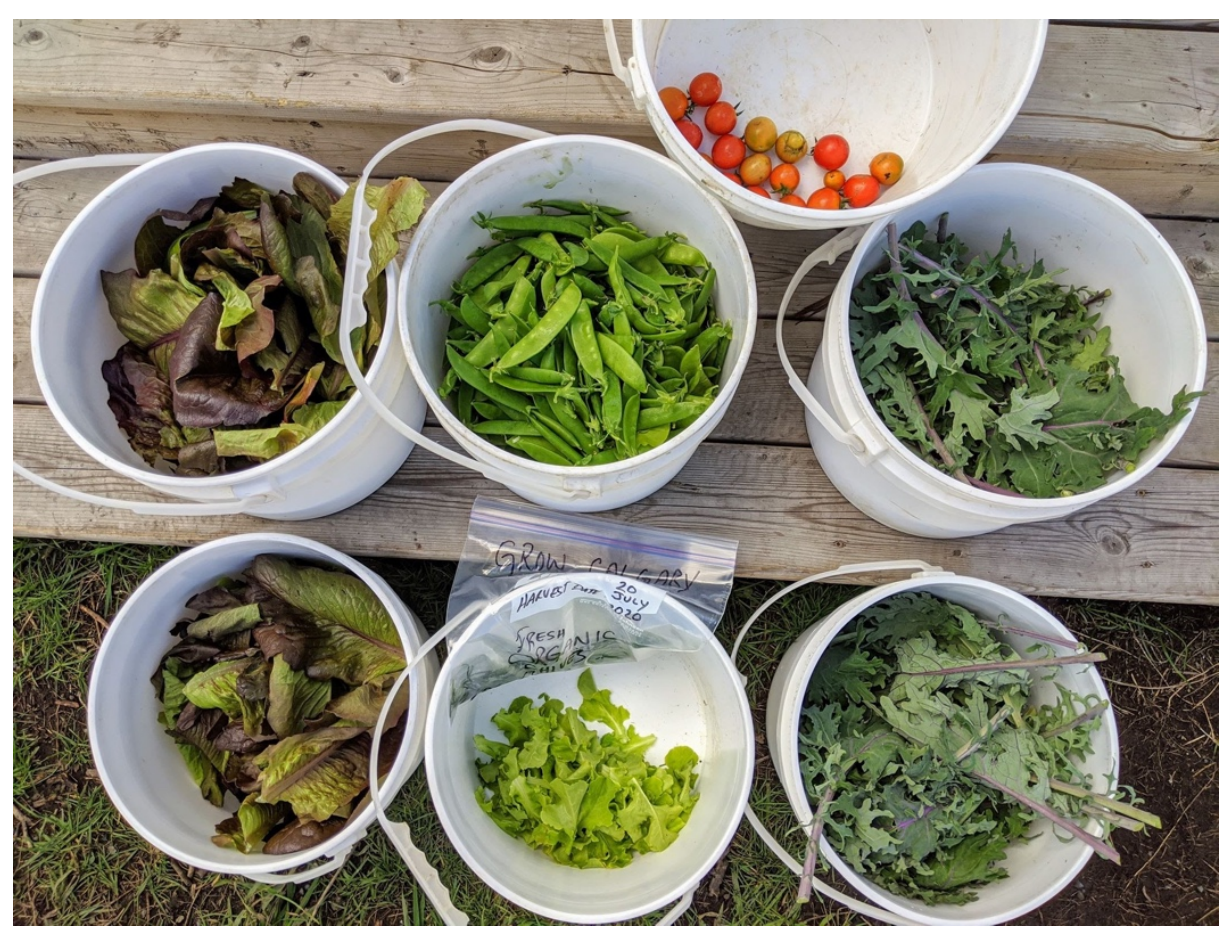

We recognize that change occurs not only at the community level, but through institutional and policy reforms. Taking part in Grow Calgary's Policy Team, we discussed the underlying politics of food production in Calgary and Alberta and planned to make recommendations to the Government of Alberta through the Local Food Engagement programme. For instance, through the \#Mow2Grow initiative, Grow Calgary advocated for changes in urban land use that would convert high maintenance grass lawns into food producing ecosystems that would attract native pollinators and increase local food resiliency. In addition to advancing political agendas concerning land use, sustainable agriculture, and gaps in food security, Grow Calgary recognizes the connection between food and shelter. Supporting Article 25 of the United Nations Declaration of Human Rights (UN General Assembly, 1949), the organization advocated for the fundamental rights to shelter through a Microhome initiative. Each living space, which was less than 200 square feet, was designed and constructed by Calgarians in a friendly competition. 
The goal was to raise awareness about the lack of affordable housing options in urban centres, and to provide alternative and feasible living conditions that could be supported at the municipal level. Addressing challenges to food security requires a holistic lens, which considers income levels, access to healthcare and education, affordable housing, available transportation, institutional barriers, and systemic inequalities. Compounded by a global pandemic and ongoing recession, the relevance and cruciality of converging food pedagogy with transformative community work has been heightened. Building upon our conceptual and theoretical foundations of food system studies, we were able to support a more sustainable food model, build community within and beyond academia, and foster social change by engaging in activist scholarship at the community level.

\section{Building bridges for transformative social change}

From the perspective of graduate students interning on a not-for-profit urban farm, we have brought to light viable pathways for incorporating experiential learning and participatory action research into Food Studies pedagogy. Aligning theory and literature with community-driven food movements may support students in contributing to food and social justice, economic well-being, social equity, and environmental conservation efforts (Clancy, 2014; Sumner et al., 2014). Volunteering on a farm during the COVID-19 pandemic also led to an improvement in our physical, emotional, and mental well-being. Being able to socially distance while contributing to essential work provided a sense of purpose during an unprecedented time. Interning as University of Calgary affiliates also brought us closer together as an academic cohort, as we could continue offering support to one another on a frequent basis. Whether we were transplanting seedlings or watering tomatoes, we could carve out time to discuss our dissertation proposals, course work, teaching assistantships, and personal struggles. These opportunities for community-building and support are not always available in conventional classroom-based learning environments. A community-driven, learner-centred platform further helped us to reflect critically upon local issues, horizontal goals, and integrated frameworks to address food insecurity. Alongside stakeholders, we were able to effect change vis-á-vis activist food pedagogy, as well as connect global to local issues concerning food access and security. Intersecting food pedagogy with a transformative agenda also furthered our abilities to grow nutritious food alongside our fellow Calgarian agrarians. We now promote other local organizations employing ecologically sustainable and socially inclusive food models grounded in agroecological frameworks, permaculture principles, regenerative techniques, and Indigenous Knowledge Systems. One such social enterprise is FoodScape Calgary, which transforms high maintenance lawns and gardens into easy-to-care-for, edible landscape ecosystems. Offering Indigenous Métis land stewardship consultations, founder Heather Morigeau designs healing spaces, such as Sacred Medicine Gardens (Figure 3), to celebrate and reclaim significant aspects of Indigenous culture. 
Volunteering with FoodScape taught us the importance of following cultural Protocol while working alongside Traditional Knowledge Keepers of Treaty 7.

Figure 3: Sacred Medicine Garden by FoodScape (photo credit: Heather Morigeau)

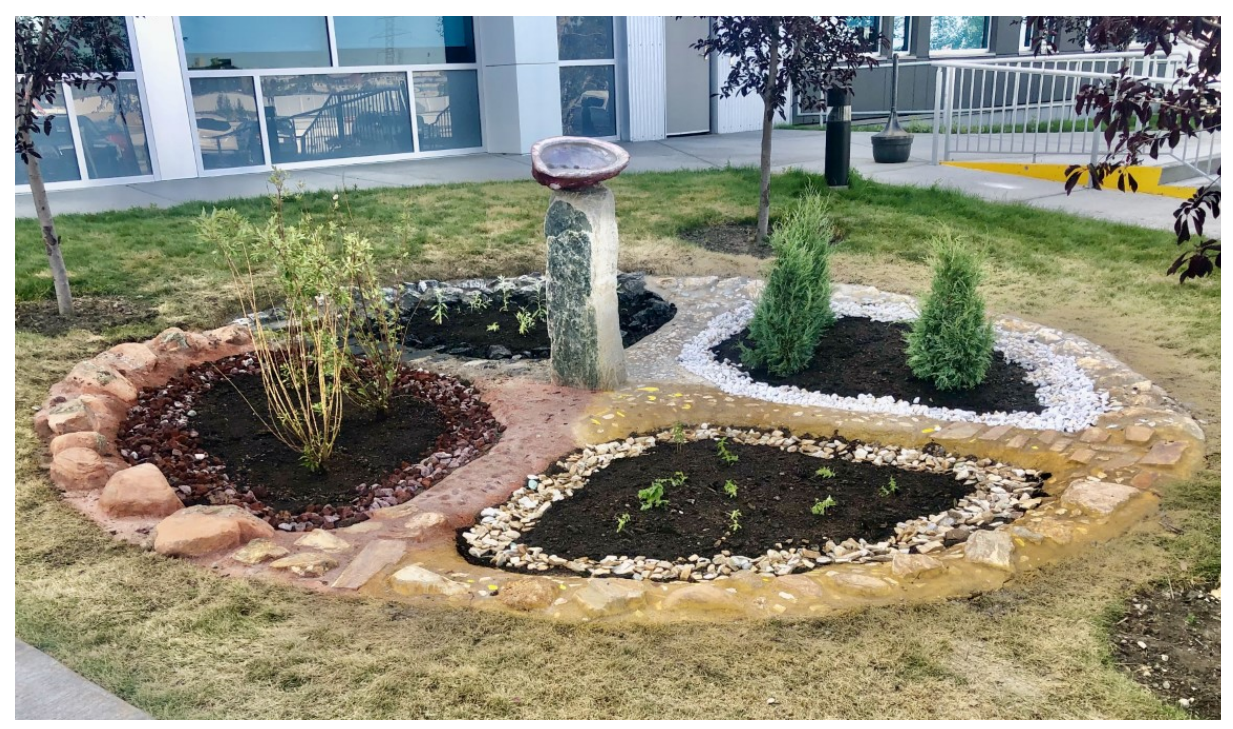

Another social ecology organization that showed us food's ability to nurture social change, cultural healing, and relationship-building was Dirt Boys Urban Farming. Run by Michael Gavin, whose motto is to "help plants grow," we learned how to reposition ourselves from producers of food to stewards of the land. Since our internship, we have further honed our professional leadership and communication skills by mobilizing knowledge about sustainable, socially just, and secured food systems through formal and informal presentations at the University of Calgary. It is our responsibility as activist scholars to promote agroecological production models that enhance social and ecological diversity, and reduce vulnerability via increased food security, access, and food sovereignty. Connecting Food Studies scholars with sustainable agrarian models through hands-on academic frameworks will further support local agrarian efforts and enhance student learning processes.

\section{Conclusions}

Through a case study approach, we presented the benefits of activist food pedagogy within the context of a University of Calgary Transformative Talent Internship with the not-for-profit farm, Grow Calgary. Harnessing our foundations in course-based Food Studies theory and literature, we engaged in sustainable farming during the COVID-19 pandemic to enhance our leadership and technical capacities in advanced urban food production. As a result, we fostered a robust network of fellow agrarians, bridged our academic and public agendas, and helped to increase 
food access and security among Calgary's most food-insecure populations. We recognize that our case study is but a small initiative at the margins. However, we argue that activist food scholarship may be incorporated into existing academic frameworks more widely to cultivate awareness and action surrounding more socially and ecologically-just food models.

Partnering with local stakeholders (i.e. farmers, social agencies, and food recipients) not only encouraged a dialogue about system inequalities surrounding food but also prompted critical reflections about our own positions relative to those systems. For future consideration, activist food pedagogy may be even more deeply grounded in community-based participatory research (CBPR) by working directly with marginalized community members to develop a plan of action, a knowledge mobilization platform, and a social justice framework determined by the communities themselves. Students enrolled in Food Studies courses could partner with existing social enterprises and farms for a semester to support an initiative deemed necessary by the organization (i.e. environmental scan, capacity-building workshops, or a "PermaBlitz," or high energy installation of a permaculture system in an urban space). These collaborations may also be tailored to an online learning environment, such as that which post-secondary institutions are facing now as a result of COVID-19. For instance, students can assist farming organizations develop strategic plans, policy reports, literature reviews, website design, social media presence, and media engagement from home. Instructors may complement these community-driven projects with guest lectures from local food activists and practitioners. Socially distanced learning activities, such as cultivating plants at home or volunteering in a neighborhood garden, may also support a more experiential Food Studies model.

In addition to addressing the limitations of virtual learning, we must also emphasize that our experiences with activist food pedagogy are place-specific (Wezel et al., 2016). The findings from our internship with Grow Calgary may not be applicable in other urban settings, where the dynamics of food insecurity and community capacity may differ drastically. Nevertheless, our case study can provide general insights into the potential benefits of activist food scholarship for students, researchers, practitioners, and food-insecure populations in urban settings.

Acknowledgements: We are grateful to the University of Calgary Faculty of Graduate Studies Transformative Talent Internship (2020) programme that supported our work with Grow Calgary through a scholarship and course credit. We thank our fellow volunteers; Chelsea Klinke and Heather Morigeau, for their permission to use their photographs; and our pre-reviewers Dr. Ben McKay, Dr. Susanne Cote, Cecilia Porter, and Veronica Lewis, for their feedback on a draft of our manuscript.

\section{References}

Akram-Lodhi, H., K. Dietz, B. Engels and B. M. McKay (Eds.) (2021) The Edward Elgar Handbook in Critical Agrarian Studies. Chelmsford: Edward Elgar. 
Alkon, A. H. \& Agyeman, J. (Eds.). (2011). Cultivating food justice: Race, class, and sustainability. MIT Press.

Alkon, A.H. \& Guthman, J. (Eds.). (2017). The new food activism: Opposition, cooperation, and collective action. University of California Press.

Bernstein, H. (2009). V.I. Lenin and A.V. Chayanov: Looking back, looking forward. The Journal of Peasant Studies, 36(1), 55-81. https://doi.org/10.1080/03066150902820289

Bernstein, H. (2010). Class Dynamics of Agrarian Change. Fernwood Publishing.

Bernstein, H. (2016). Agrarian political economy and modern world capitalism: the contributions of food regime analysis. The Journal of Peasant Studies, 43(3), 611-647, DOI: $10.1080 / 03066150.2015 .1101456$

Borras, S.M., Franco, J. C., Góm, S., Kay, C., \& Spoor, M.. (2012). Land grabbing in Latin America and the Caribbean. Journal of Peasant Studies, 39(3-4), 845-72. doi:10.1080/03066150.2012.679931

Calhoun, C. (2008). Foreword: engaging contradictions: theory, politics, and methods of activist scholarship. In: C. R. Hale (Ed.), Engaging Contradictions: Theory, Politics, and Methods of Activist Scholarship (pp. Xiii-xxv). Global, area, and international archive. University of California Press, California, USA.

Casas-Cortés, M. Isabel., Osterweil, Michal., \& Powell, D. E. (2008). Blurring boundaries: Recognizing knowledge-practices in the study of social movements. Anthropological Quarterly, 81(1), 17-58. https://doi.org/10.1353/anq.2008.0006

Choudry, A., \& Kapoor, D. (2010). Learning from the ground up: Global perspectives on social movements and knowledge production. In A. Choudry \& D. Kapoor (Eds.), Learning from the Ground Up (pp. 1-13). Palgrave Macmillan US. https://doi.org/10.1057/9780230112650_1

Clancy, K. (2014). Digging Deeper: Bringing a systems approach to food systems: Food system governance. Journal of Agriculture, Food Systems, and Community Development, 4(2), 3-6. http://dx.doi.org/10.5304/jafscd.2014.042.012

Derickson, K. D., \& Routledge, P. (2015). Resourcing scholar-activism: Collaboration, transformation, and the production of knowledge. The Professional Geographer, 67(1), 1-7. https://doi.org/10.1080/00330124.2014.883958

Dole, S., Bloom, L., \& Kowalske, K. (2015). Transforming pedagogy: Changing perspectives from teacher-centered to learner-centered. Interdisciplinary Journal of Problem-Based Learning, 10(1). https://doi.org/10.7771/1541-5015.1538 
Duncan, J., Claeys, P., Rivera-Ferre, M. G., Oteros-Rozas, E., Van Dyck, B., Plank, C., \& Desmarais, A. A. (2019). Scholar-activists in an expanding European food sovereignty movement. The Journal of Peasant Studies, 48(4), 1-26. https://doi.org/10.1080/03066150.2019.1675646

Edelman, M. \& Wolford, W. (2017) 'Critical Agrarian Studies in theory and practice'. Antipode, 49(4), 959-976. http://doi.org/10.1111/anti.12326

Francis, C., Breland, T. A., Østergaard, E., Lieblein, G., \& Morse, S. (2012). PhenomenonBased Learning in Agroecology: A Prerequisite for Transdisciplinarity and Responsible Action. Journal of Sustainable Agriculture, 120911083006009. https://doi.org/10.1080/10440046.2012.717905

Francis, C. A., Jordan, N., Porter, P., Breland, T. A., Lieblein, G., Salomonsson, L., Sriskandarajah, N., Wiedenhoeft, M., DeHaan, R., Braden, I., \& Langer, V. (2011). Innovative education in agroecology: Experiential learning for a sustainable agriculture. Critical Reviews in Plant Sciences, 30(1-2), 226-237. https://doi.org/10.1080/07352689.2011.554497

Galt, R. E., Parr, D., Van Soelen Kim, J., Beckett, J., Lickter, M., \& Ballard, H. (2013). Transformative food systems education in a land-grant college of agriculture: The importance of learner-centered inquiries. Agriculture and Human Values, 30(1), 129 142. https://doi.org/10.1007/s10460-012-9384-8

Galt, R. E., Clark, S. F., \& Parr, D. (2012). Engaging values in sustainable agriculture and food systems education: Toward an explicitly values-based pedagogical approach. Journal of Agriculture, Food Systems, and Community Development, 2(3), 43-54. http://dx.doi.org/10.5304/jafscd.2012.023.006

Hilimire, K., Gillon, S., McLaughlin, B. C., Dowd-Uribe, B., \& Monsen, K. L. (2014). Food for thought: Developing curricula for sustainable food systems education programs. Agroecology and Sustainable Food Systems, 38(6), 722-743. https://doi.org/10.1080/21683565.2014.881456

Horrigan, L., Lawrence, R. S., \& Walker, P. (2002). How sustainable agriculture can address the environmental and human health harms of industrial agriculture. Environmental Health Perspectives, 110(5), 445-456. https://doi.org/10.1289/ehp.02110445

Huba, M. E., \& Freed, J. E. (2000). Learner-centered assessment on college campuses: Shifting the focus from teaching to learning. Allyn and Bacon.

IRP (2019). Global Resources Outlook 2019: Natural Resources for the Future We Want. Oberle, B., Bringezu, S., Hatfeld-Dodds, S., Hellweg, S., Schandl, H., Clement, J., and Cabernard, L., Che, N., Chen, D., Droz-Georget, H., Ekins, P., FischerKowalski, M., Flörke, M., Frank, S., Froemelt , A., Geschke, A., Haupt , M., Havlik, P., Hüfner, R., Lenzen, M., Lieber, M., Liu, B., Lu, Y., Lutter, S., Mehr, J., Miatto, A., Newth, D., 
Oberschelp , C., Obersteiner, M., Pfster, S., Piccoli, E., Schaldach, R., Schüngel, J., Sonderegger, T., Sudheshwar, A., Tanikawa, H., van der Voet, E., Walker, C., West, J., Wang, Z., Zhu, B. A Report of the International Resource Panel. United Nations Environment Programme. Nairobi, Kenya.

Knezevic, I., Blay-Palmer, A., Levkoe, C. Z., Mount, P., \& Nelson, E. (Eds.). (2017). Nourishing Communities: From Fractured Food Systems to Transformative Pathways. Springer International Publishing. https://doi.org/10.1007/978-3-319-57000-6

Kremen, C., Iles, A., \& Bacon, C. (2012). Diversified Farming Systems. Ecology and Society, 17(4). http://www.jstor.org/stable/26269193

Lawlor, K. \& Hornyak, M. (2012). Smart goals: How the application of smart goals can contribute to achievement of student learning outcomes. Developments in Business Simulation and Experiential Learning, 39, 259-267.

Levkoe, C. Z., Hammelman, C., Reynolds, K., Brown, X., Chappell, M. J., Salvador, R., \& Wheeler, B. (2020). Scholar-activist perspectives on radical food geography: Collaborating through food justice and food sovereignty praxis. Human Geography, 194277862096203. https://doi.org/10.1177/1942778620962036

Lieblein, G., \& Francis, C. (2007). Towards responsible action through agroecological education. Italian Journal of Agronomy, 2(2), 83. https://doi.org/10.4081/ija.2007.83

Lieblein, G., Østergaard, E., \& Francis, C. (2004). Becoming an agroecologist through action education. International Journal of Agricultural Sustainability, 2(3), 147-153. https://doi.org/10.1080/14735903.2004.9684574

McEntee, J. C., \& Naumova, E. N. (2012). Building capacity between the private emergency food system and the local food movement: Working toward food justice and sovereignty in the Global North. Journal of Agriculture, Food Systems, and Community Development, 3(1), 235-253. https://doi.org/10.5304/jafscd.2012.031.012

McKay, B. M. (2017). Agrarian extractivism in Bolivia. World Development, 97, 199-211. https://doi.org/10.1016/j.worlddev.2017.04.007

Meek, D., \& Tarlau, R. (2016). Critical food systems education (CFSE): Educating for food sovereignty. Agroecology and Sustainable Food Systems, 40(3), 237-260. https://doi.org/10.1080/21683565.2015.1130764

Niewolny, K. L., \& Lillard, P. T. (2010). Expanding the boundaries of beginning farmer training and program development: A review of contemporary initiatives to cultivate a new generation of American farmers. Journal of Agriculture, Food Systems, and Community Development, 1(1), 65-88.https://doi.org/10.5304/jafscd.2010.011.010

Parr, D. M., \& Trexler, C. J. (2011). Students' experiential learning and use of student farms 
in sustainable agriculture education. Journal of Natural Resources and Life Sciences Education, 40(1), 172-180. https://doi.org/10.4195/jnrlse.2009.0047u

Parr, D. M., Trexler, C. J., Khanna, N. R., \& Battisti, B. T. (2007). Designing sustainable agriculture education: Academics' suggestions for an undergraduate curriculum at a land grant university. Agriculture and Human Values, 24(4), 523-533. https://doi.org/10.1007/s10460-007-9084-y

Reynolds, K., Block, D., \& Bradley, K. (2018). Food justice scholar-activism and activist-scholarship. ACME: An International Journal for Critical Geographies, 17(4), 988-998.

Salomonsson, L., Nilsson, A., Palmer, S., Roigart, A., \& Francis, C. (2009). Farming systems education: Case study of Swedish test pilots. Renewable Agriculture and Food Systems, 24(1), 48-59. https://doi.org/10.1017/S1742170508002408

Stephens, P., Nelson, C., Levkoe, C., Mount, P., Knezevic, I., Blay-Palmer, A., \& Martin, M. A. (2019). A perspective on social economy and food systems: Key insights and thoughts on future research. Canadian Food Studies/La Revue canadienne des études sur l'alimentation, 6(3), 5-17.

Sumner, J., McMurtry, J. J., \& Renglich, H. (2014). Leveraging the local: Cooperative food systems and the local organic food co-ops network in Ontario, Canada. Journal of Agriculture, Food Systems, and Community Development, 4(3), 47-60. http://dx.doi.org/10.5304/jafscd.2014.043.004

Transformative Talent Internships. (2020). University of Calgary: Faculty of Graduate Studies. Retrieved October 25, 2020 from https:/grad.ucalgary.ca/my-gradskills/experientiallearning/internships/students

United Nations General Assembly (1949). Universal Declaration of Human Rights. 3381. Department of State, United States of America.

Wezel, A., Brives, H., Casagrande, M., Clément, C., Dufour, A., \& Vandenbroucke, P. (2016). Agroecology territories: Places for sustainable agricultural and food systems and biodiversity conservation. Agroecology and Sustainable Food Systems, 40(2), 132-144. https://doi.org/10.1080/21683565.2015.1115799

Wiedenhoeft, M., Simmons, S., Salvador, R., McAndrews, G., Francis, C., King, J., \& Hole, D. (2003). Agroecosystems analysis from the grass roots: A multidimensional experiential learning course. Journal of Natural Resources and Life Sciences Education, 32(1),7379. http://doi.org/10.2134/jnrlse.2003.0073 